\title{
TINJAUAN YURIDIS PEMUNGUTAN LIAR DI JEMBATAN BARELANG KOTA BATAM BERDASARKAN PERATURAN DAERAH KOTA BATAM NOMOR 3 TAHUN 2018 TENTANG PENYELENGGARAAN DAN RETRIBUSI PARKIR
}

\author{
Tantimin $^{1}$ \\ Elvi $^{2}$
}

\begin{abstract}
This Final Project Research aims to analyze and find out the collection of parking at the Batam City Barelang Bridge including illegal collection and to describe the role of the Batam City Transportation Agency in implementing or enforcing Batam City Regulation Number 3 of 2018 concerning Parking Management and Retribution.

The research methodology used by the author is empirical legal research by examining the results of observations and interviews and is supported by legal theories and legislation in force in Indonesia. The type of data used is primary data as primary data and secondary data as supporting data consisting of primary, secondary and tertiary legal materials. This Legal Research is analyzed descriptively qualitatively.

The results of the study that the authors obtained from observations and interviews were then reviewed from the theory of Economic Development according to Anwar that the tariffs for parking at the Batam City Barelang Bridge provided were not in accordance with Batam City Regulation Number 3 of 2018 concerning the Implementation and Retribution of Parking and Previously the City Transportation Agency Batam insists there are no rules that specify parking fees for tourist areas and the Batam City Transportation Agency as the related agency appointed by the Batam City Government to play an important role in Implementing or Enforcing Batam City Regulation Number 3 of 2018 concerning Implementation and Retribution of Parking Limitation as the Regulator, Facilitator, and Dynamicsator
\end{abstract}

Keywords: Parking Rates, Barelang Bridge, Transportation Agency, Batam City

\footnotetext{
${ }^{1}$ Fakultas Hukum Universitas Internasional Batam

${ }^{2}$ Fakultas Hukum Universitas Internasional Batam
} 


\section{A. Latar Belakang}

Pemungutan liar atau biasa disebut pungli dapat diartikan sebagai pemungutan yang dilakukan oleh dan untuk kepentingan pribadi oknum petugas secara tidak sah atau melanggar aturan. Pemugutan liar merupakan salah satu bentuk penyalahgunaan wewenang yang memiliki tujuan untuk memudahkan urusan atau memenuhi kepentingan dari pihak pembayar pungutan. Sehingga dapat disimpulkan bahwa pemungutan liar melibatkan dua pihak atau lebih, baik itu pengguna jasa ataupun oknum petugas yang biasa melakukan kontak langsung untuk melakukan transaksi rahasia maupun terang-terangan, dimana pada umumnya pemungutan liar yang terjadi pada tingkat lapangan dilakukan secara singkat dan biasanya berupa uang. Banyak istilah lain yang sering dipergunakan oleh masyarakat mengenai arti kata pemungutan liar seperti uang sogok, uang pelicin, uang semir, salam tempel, uang siluman, uang jasa, uang titip, Undang-Undang 2000, ongkos administrasi, uang ikhlas, 3S (Senang Sama Senang), dan lain sebagainya.

Setiap orang dapat melakukan pemungutan liar tak terkecuali pejabat negara maupun swasta meski telah dilarang, dimana adanya faktor-faktor yang mendorong dan memberikan peluang untuk terjadinya praktik pemungutan liar antara lain seperti birokrasi yang berbelit-belit, pengumpulan dana yang tidak dilindungi oleh Undang-Undang atau peraturan, sistem yang tidak "open management", wewenang yang tidak terkendali serta motivasi kepentingan pribadi untuk memperkaya diri. Salah satu sumber permasalahan terbesar sering terjadinya praktik pemungutan liar yaitu terletak pada pengawasan dan pertanggungjawaban pelaksanaan pembangunan serta pengaturan hak dan kewajiban lembagalembaga negara dalam urusan penyelenggaraan kepentingan perseorangan dan kepentingan masyarakat.

Pemungutan liar menjadi salah satu bentuk tindak pidana yang sudah sangat sering terdengar di telinga masyarakat. Walaupun sebenarnya dalam Kitab Undang-Undang Hukum Pidana (KUHP) tidak satupun ditemukan Pasal mengenai tindak pidana pemungutan liar atau delik pungli. Pada dasarnya pemungutan liar dan korupsi merupakan perbuatan yang sama dimana kedua perbuatan itu menggunakan kekuasaan untuk tujuan memperkaya diri dengan cara melawan hukum. Sehingga secara tersirat dapat kita temukan di dalam rumusan korupsi pada Pasal 12 huruf e Undang-Undang Nomor 20 Tahun 2001 jo Pasal 423 KUHP yang dirujuk dalam Pasal 1 ayat (1) huruf c Undang-Undang Nomor 3 Tahun 1971 tentang Pemberantasan Tindak Pidana Korupsi, dan Pasal 12 Undang-Undang Nomor 31 Tahun 1999 tentang Pemberantasan Tindak Pidana Korupsi (Undang-Undang ini mencabut Undang-Undang Nomor 3 Tahun 1071) sebagai tindak pidana korupsi, yang kemudian dirumuskan ulang pada Undang-Undang Nomor 20 Tahun 2001 tentang erubahan Atas Undang-Undang Nomor 31 Tahun 1999 tentang Pemberantasan Tindak Pidana Korupsi. 
Di Jembatan Barelang sebagai ikon pariwisata Kota Batam kerap terjadi tindakan pemungutan liar terkait biaya parkir yang dilakukan oleh pejabat aparatur negara ataupun pihak swasta yang terlibat. Kegiatan tersebut bukan merupakan lokasi yang dapat menyediakan fasilitas parkir sebagaimana dimaksud pada Pasal 2 Peraturan Daerah Kota Batam Nomor 3 Tahun 2018 tentang Penyelenggaraan dan Retribusi Parkir. Walikota menetapkan lokasi fasilitas parkir untuk ketertiban, keamanan, kelancaran lalu lintas pada tempat-tempat tertentu dalam wilayah daerah dapat dibedakan menjadi :

1. Lokasi parkir di Rumija/tepi jalan umum.

2. Lokasi parkir di luar Rumija/tempat khusus parkir.

3. Lokasi parkir tertentu yang digunakan sebagai lokasi parkir tidak tetap.

Dan berkernaan parkir juga terdapat izin penyelenggaran parkir yang diberikan oleh Walikota atau pejabat petunjuk (Dinas Perhubungan) sesuai dengan Pasal 18 Peraturan Daerah Kota Batam Nomor 3 Tahun 2018 tentang Penyelenggaraan dan Retribusi Parkir. Pengertian Parkir sendiri yaitu keadaan kendaraan berhenti atau tidak bergerak untuk beberapa saat dan ditinggalkan pengemudinya. Kemudian, pengertian dari Ruang Milik Jalan atau disingkat Rumija yaitu sejalur tanah tertentu di luar ruang manfaat jalan yang masih menjadi bagian dari ruang milik jalan yang dibatasi oleh tanda batas ruang milik jalan yang dimaksudkan memenuhi persyaratan keluasan keamanan penggunaan jalan antara lain untuk keperluan pelebaran ruang manfaat jalan pada masa yang akan datang. Salah satu kenyataan adalah terdapat beberapa juru parkir (jukir) liar yang menarik uang parkir sebesar Rp 5.000,- sampai Rp 10.000,- Setiap pelaku pungli tersebut memiliki karcis parkir illegal berwarna kuning dan berlogo Dinas Perhubungan (Dishub). Dalam menjalankan tugasnya pelaku selalu menarik uang di pintu masuk Dendang Melayu yang memiliki lahan parkir jembatan Barelang Kota Batam.

Kota Batam telah menerbitkn Peraturan Daerah Kota Batam Nomor 3 Tahun 2018 tentang Penyelenggaraan dan Retribusi Parkir yang berfungsi sebagai aturan yang berwenang untuk melakukan pemungutan retribusi pelayanan parkir di tepi jalan umum dan retribusi tempat khusus parkir oleh Pemerintah Daerah. Dengan diterbitkannya Peraturan Daerah Kota Batam Nomor 3 Tahun 2018 tentang Penyelenggaraan dan Retribusi Parkir ini diharapkan dapat memberantas bersih kasus pungli yang sering terjadi pada masyarakat di Jembatan Barelang Kota Batam.

Dinas Perhubungan Kota Batam diberikan wewenang khusus sebagai penyidik untuk melakukan penyidikan tindak pidana di bidang pelanggaran peraturan daerah sebagaimana dimaksud dalam Undangundang Hukum Acara Pidana yang berlaku. Para pelaku pelanggaran tersebut dapat diberikan sanksi administrasi berupa: a. Peringatan tertulis paling banyak 3 (tiga) kali; b. Penghentian sementara kegiatan; c. 
Pembatalan izin; dan d. Pencabutan izin, hal ini telah disebutkan pada Pasal 57 ayat (1) Peraturan Daerah Kota Batam Nomor 3 Tahun 2018 tentang Penyelenggaraan dan Retribusi Parkir. Dilanjutkan dalam Pasal 62 ayat (1) Peraturan Daerah Kota Batam Nomor 3 Tahun 2018 tentang Penyelenggaraan dan Retribusi Parkir bahwa pelanggaran terhadap ketentuan sebagaimana dimaksud dipidana dengan pidana kurungan paling lama 3 (tiga) bulan atau denda paling banyak Rp 50.000.000,- (lima puluh juta rupiah).

Berdasarkan uraian diatas, dapat dilihat bahwa Kota Batam masih terdapat pungli terkait parkir yang sering terjadi pada masyarakat di Jembatan Barelang padahal sudah ada aturan yang telah diterbitkan Peraturan Daerah Kota Batam Nomor 3 Tahun 2018 tentang Penyelenggaraan dan Retribusi Parkir yang berfungsi sebagai aturan yang berwenang untuk melakukan pemungutan retribusi pelayanan parkir di tepi jalan umum dan retribusi tempat khusus parkir oleh Pemerintah Daerah,

Berdasarkan latar belakang tersebut diatas penulis tertarik untuk membahas jurnal ini dengan rumusan masalah yaitu: Pertama Apakah pemungutan liar di Jembatan Barelang Kota Batam berdasarkan Peraturan Daerah Kota Batam Nomor 3 Tahun 2018 tentang Penyelenggaraan dan Retribusi Parkir? Kedua Bagaimana peran Dinas Perhubungan Kota Batam dalam menjalankan atau menegakkan Peraturan Daerah Kota Batam Nomor 3 Tahun 2018 tentang Penyelenggaraan dan Retribusi Parkir di Jembatan Barelang?

\section{B. Metode Penelitian}

Dalam upaya proses penelitian, peneliti menggunakan metode penelitian empiris karena objek yang diteliti berada di lapangan dan fungsi dari pada penelitian empiris untuk menganalisis hukum yang dilihat sebagai perilaku masyarakat yang berpola dalam kehidupan masyarakat yang selalu berinteraksi dan berhubungan dalam aspek kemasyarakatan. Penelitian ini bertujuan untuk menggambarkan realita yang sesuai dengan fenomena secara rinci dan tuntas.

Penelitian hukum empiris ini menggunakan data primer yaitu data yang diperoleh langsung dari sumbernya diamati dan dicatat untuk pertama. Data primer dalam penelitian ini dibagi menjadi dua yang pertama diperoleh melalui observasi dan yang kedua peneliti peroleh dengan cara wawancara dan data sekunder terdiri dari tiga bahan hukum yaitu: Pertama, bahan Hukum Primer yaitu Undang-undang Nomor 1 Tahun 1946 KUHP, Undang-undang Nomor 28 Tahun 2009 tentang Pajak Daerah dan Retribusi Daerah, Peraturan Daerah Kota Batam Nomor 3 Tahun 2018 tentang Penyelenggaraan dan Retribusi Parkir. Kedua, bahan Hukum Sekunder terdiri dari buku-buku hukum, jurnal hukum, karya tulis ahli hukum. Ketiga, dan bahan Hukum Tersier yaitu Kamus dan Ensiklopedia. 
Peneliti menggunakan metode pendekatan kualitatif sebagai proses penelitian yang menghasilkan data deskriptif berupa kata-kata tertulis atau lisan dari orang-orang atau perilaku yang diamati. Mengingat bahwa data deskriptif adalah suatu metode dalam meneliti suatu kelompok manusia, suatu objek, suatu kondisi, suatu sistem pemikiran ataupun suatu kelas peristiwa pada masa sekarang. Dalam penelitian ini, peneliti mendeskripsikan pemungutan parkir di Jembatan Barelang berdasarkan Peraturan Daerah Kota Batam Nomor 3 Tahun 2018 tentang Penyelenggaraan dan Retribusi Parkir.

\section{Hasil Penelitian dan Pembahasan}

1. Pemungutan Liar di Jembatan Barelang Berdasarkan Peraturan Daerah Kota Batam Nomor 3 Tahun 2018 Tentang Penyelenggaraan dan Retribusi Parkir.

Pemungutan liar tediri dari kata pemungutan dan liar. Menurut Kamus Besar Bahasa Indonesia (KBBI) kata pemungutan yaitu mengambil atau mengutip dan kata liar yaitu tidak resmi atau tanpa izin dari yang berwenang. Jadi pemungutan liar adalah meminta sesuatu (uang dan sebagainya) kepada seseorang (lembaga, perusahaan, dan sebagainya) tanpa menurut peraturan yang lazim.

Pemungutan berarti bea, iuran, dan tarif. Liar berarti tidak teratur, tidak menurut aturan, tidak resmi, tanpa izin dari yang berwenang. Pemungutan liar atau pungli adalah pengenaan biaya di tempat yang tidak seharusnya biaya dikenakan atau dipungut. Dapat disimpulkan bahwa pemungutan liar adalah kegiatan memungut sejumlah uang iuran/tarif yang dilakukan oleh sesorang atau kelompok diluar wewenang tugas dan tanggung jawabnya tanpa memiliki izin resmi.

Dengan diberlakukannya Peraturan Pemerintah Nomor 79 Tahun 2013 tentang Jaringan Lalu Lintas dan Angkutan Jalan, dan dengan perkembangan yang pesat dan pertambahan kendaraan bermotor yang makin meningkat dan sangat tinggi dari tahun ke tahun, selain mengakibatkan meningkatnya kebutuhan pelayanan tempat parkir juga berpengaruh terhadap pembinaan penyelenggaraan tempat parkir sebagai bagian dari sistem lalu lintas di Kota Batam. Oleh karena itu perlu dilakukan penyesuaian terhadap Peraturan Daerah Nomor 1 Tahun 2012 Tentang Penyelenggaraan dan Retribusi Parkir Di Kota Batam.

Penyesuaian tersebut menggantikan ketentuan Penyelenggaraan dan Retribusi Parkir menjadi Penyelenggaraan Fasilitas dan Retribusi Parkir sebagamana diatur dalam Peraturan Daerah Kota Batam Nomor 3 Tahun 2018 tentang Penyelenggaraan dan Retribusi Parkir. Kebutuhan akan pengaturan pelayanan parkir bagi masyarakat, diartikan tidak saja pada ketersedian tempat parkir, juga mengarah kepada besaran biaya penyelenggaraan pelayanannya, sehingga 
didapat kepastian pola penetapan tarif oleh Pihak Penyelenggara maupun yang dilaksanakan oleh Pemerintah Kota Batam, sebagaimana hal ini tertuang dalam Undang-Undang Nomor 28 Tahun 2009 tentang Pajak Daerah dan Retribusi Daerah, dimana daerah berwenang untuk melakukan pemungutan retribusi pelayanan parkir di tepi jalan umum dan retribusi tempat khusus parkir oleh Pemerintah Daerah.

Kewenangan penyelenggaraan parkir oleh Pemerintah Kota Batam menurut ketentuan Peraturan Daerah Kota Batam Nomor 3 Tahun 2018 tentang Penyelenggaraan dan Retribusi Parkir, dapat dikerjasamakan dengan badan usaha sebaai upaya peningkatan pelayanan dan memaksimalkan target penerimaan daerah dari penerimaan lain-lain yang sah, dan selain dari pada itu, retribusi yang menjadi kewenangan Pemerintah Kota untuk memungutnya pun dapat di borongkan pemungutannya kepada Pihak Ketiga.

Pada peneltian ini diperlukan suatu pembangunan ekonomi yang harus dipandang sebagai suatu proses agar pola keterkaitan dan saling mempengaruhi antara faktor-faktor dalam pembangunan ekonomi dapat diamati dan dianalisis. Menurut Anwar teori-teori yang menjelaskan tentang pertumbuhan suatu daerah dimana runtutan peristiwa yang terjadi dan dampaknya pada peningkatan kegiatan ekonomi dan taraf kesejahteraan masyarakat dari satu tahap pembangunan ke tahap pembangunan berikutnya. Dalam proses pembangunan ekonomi, masalah percepatan pertumbuhan ekonomi antardaerah adalah berbeda, sehingga mengakibatkan ketimpangan regional tidak dapat dihindari mengingat adanya perbedaan dalam kekayaan sumber daya yang dimiliki antara daerah yang satu dengan daerah yang lainya. Dasar pelaksanaan pembangunan itu sendiri serta konsentrasi kegiatan ekonomi juga berbeda.

Teori ini mengangap bahwa pertumbuhan ekonomi yang terjadi pada suatu daerah diakibatkan oleh faktor-faktor ekonomi yang ada di daerah itu sendiri. Dalam penelitian ini dapat diketahui bahwa Pertumbuhan ekonomi Batam terus menurun pada beberapa tahun terakhir. Angka PDRB selalu menunjukkan tren penurunan meskipun masih pada angka positif. Antara 2015 dan 2016 terdapat 110 perusahaan berhenti beroperasi, dan 53 perusahaan kemudian menyusul berhenti beroperasi di awal 2017.

Cara mengatasi penurunan ini, Badan Pengusahaan Batam sangat serius mengembangkan sektor pariwisata agar pertumbuhan ekonomi pulau tersebut menjadi lebih baik dan meningkat setiap tahunnya dan untuk sektor pariwisata tersebut diperlukan suatu fasilitas yang memadai, dalam hal ini Jembatan Barelang merupakan salah satu ikon pariwisata Kota Batam yang ramai dikunjungi wisatawan lokal maupun mancanegara, dengan ramainya 
pengunjung di Jembatan Barelang wisatawan yang memakirkan kendaraannya selalu mengeluh dengan tarif parkir yang tidak wajar dimana parkir tersebut berkisaran jumlah nominal tarif retribusi sebesar Rp 10.000,- (sepuluh ribu rupiah) khusus untuk roda empat. Selain itu, penulis juga melihat pengunjung yang menggunakan kendaraan roda dua membayar Rp 5.000,- (lima ribu rupiah).

Sedangkan tarif parkir yang diatur oleh Pemerintah Kota Batam yang besaran dan rincian tarif parkir kendaraan di tempat khusus parkir berdasarkan Pasal 20 Peraturan Daerah Kota Batam Nomor 3 Tahun 2018 tentang Penyelenggaraan dan Retribusi Parkir Batam:

a. Mobil Penumpang/Van/ Pick Up /Taksi

1) Untuk 1 (satu) kali parkir 2 (dua) jam pertama sebesar Rp. 2.000,- (dua ribu rupiah).

2) Untuk setiap 1 (satu) jam berikutnya sebesar Rp. 1.000,(seribu rupiah).

3) Tarif parkir maksimal sebesar Rp. 30.000,- (tiga puluh ribu rupiah) per hari atau 24 jam tanpa menggunakan layanan VIP/Vallet; dan

4) Tarif layanan VIP/Vallet untuk setiap parkir 1 (satu) jam pertama sebesar Rp. 30.000,- (tiga puluh ribu rupiah).

b. Sepeda Motor

1) Untuk setiap parkir 2 (dua) jam pertama sebesar Rp. 1.000,(seribu rupiah).

2) Untuk setiap 1 (satu) jam berikutnya sebesar Rp. 500,- (lima ratus rupiah), dan

3) Tarif parkir maksimal sebesar Rp. 15.000,- (lima belas ribu rupiah) per hari atau 24 (dua puluh empat) jam.

c. Bus/Truck

1) Untuk setiap parkir 2 (dua) jam pertama sebesar Rp. 3.000,(tiga ribu rupiah)

2) Untuk setiap 1 (satu) jam berikutnya sebesar Rp. 1.500,(seribu lima ratus rupiah); dan

3) Tarif parkir maksimal sebesar Rp 50.000,- (lima puluh ribu rupiah).

4) Tidak dikenakan tarif parkir apabila masuk dan keluar area layanan parkir paling lama 15 (lima belas) menit.

Berdasarkan Pasal 64 Undang-undang Nomor 28 Tahun 2009 tentang Pajak Daerah dan Retribusi Daerah menjelaskan bahwa dasar pengenaan pajak parkir adalah jumlah pembayaran atau yang 
seharusnya dibayar kepada penyelenggara tempat parkir, dimana dasar pengenaan pajak parkir sebagaimana dimaksud dapat ditetapkan dengan Peraturan Daerah dan jumlah yang seharusnya dibayar sebagaimana dimaksud termasuk potongan harga Parkir dan Parkir cuma-cuma yang diberikan kepada penerima jasa Parkir. Selanjutnya untuk tarif pajak sudah diatur dalam Pasal 65 Undang-undang Nomor 28 Tahun 2009 tentang Pajak Daerah dan Retribusi Daerah yang menjelaskan bahwa tarif pajak parkir ditetapkan paling tinggi sebesar $30 \%$ (tiga puluh persen) dan tarif pajak parkir ditetapkan dengan Peraturan Daerah.

Berdasarkan hasil observasi dan wawancara yang penulis lakukan di Jembatan Barelang, dapat diketahui bahwa biaya tarif untuk parkir yang diberikan tidak sesuai dengan Peraturan Daerah Kota Batam Nomor 3 Tahun 2018 tentang Penyelenggaraan dan Retribusi Parkir dan Dinas Perhubungan sendiri menyatakan bahwa retribusi yang ditarik oleh oknum juru parkir di Jembatan I Barelang illegal dan bukan termasuk retribusi parkir Dinas Perhubungan. Dikatakan illegal karena tidak masuk kas daerah serta besaran yang dikutip tidak sesuai dengan Peraturan Daerah Kota Batam Nomor 3 Tahun 2018 tentang Penyelenggaraan dan Restribusi Parkir.

Sebelumnya Dinas Perhubungan Kota Batam menegaskan tidak ada aturan yang mengkhususkan tarif parkir untuk kawasan wisata. Aturan untuk tarif parkir kawasan wisata itu sebenarnya tidak ada, oleh karena itu Dinas Perhubungan Kota Batam belum berani masuk. Selama ini parkir di kawasan wisata Jembatan Barelang dan sekitarnya belum kelola. Jikalau ada pungutan itu merupakan pungutan liar, dan sampai saat ini pihak Dinas Perhubungan Kota Batam belum bisa ambil alih untuk mengelola parkir disana. Karena lokasi itu belum termasuk titik parkir. Titik parkir tersebut dari Wali Kota, dimana ada surat keputusannya dan tidak bukan. Masyarakat yang menjadi korban berhak tidak membayar dan melapor kepada aparat keamanan yang berada disana agar para juru parkir liar tersebut dapat ditindak tegas.

2. Peran Dinas Perhubungan Kota Batam dalam Menjalankan atau Menegakkan Peraturan Daerah Kota Batam Nomor 3 Tahun 2018 tentang Penyelenggaraan Dan Retribusi Parkir

Dinas Perhubungan Kota Batam selaku dinas terkait yang ditunjuk Pemerintah Kota Batam untuk berperan penting dalam menjalankan atau menegakkan Peraturan Daerah Kota Batam Nomor 3 Tahun 2018 tentang Penyelenggaraan Dan Retribusi Parkir memiliki seperangkat perilaku yang diharapkan dapat memberikan kontribusi yang bersifat luas bagi Kota Batam dinyatakan sebagai struktur. Struktur organisasi memiliki fungsi-fungsi yang harus mereka jalani 
agar tercapai tujuan dari peran pembentukan instansi pemerintah tersebut.

Untuk memperoleh gambaran mengenai peran Dinas Perhubungan dalam menjalankan atau menegakkan Peraturan Daerah Kota Batam Nomor 3 Tahun 2018 tentang Penyelenggaraan dan Retribusi Parkir disajikan pertanyaan-pertanyaan dalam bentuk wawancara dan dilakukan observasi langsung sebagai berikut:

a. Regulator

Dinas Perhubungan Kota Batam sebagai regulator menyiapkan arah untuk menjalankan atau menegakkan Peraturan Daerah Kota Batam Nomor 3 Tahun 2018 tentang Penyelenggaraan Dan Retribusi Parkir. Sebagai regulator, Dinas Perhubungan Kota Batam memberikan acuan dasar kepada masyarakat. Acuan tersebut digunakan sebagai instrumen untuk mengatur segala kegiatan pelaksanaan Peraturan Daerah Kota Batam Nomor 3 Tahun 2018 tentang Penyelenggaraan dan Retribusi Parkir.

Terkait dengan tarif parkir Dinas Perhubungan Kota Batam telah mengeluarkan produk hukum berupa Peraturan Daerah Kota Batam Nomor 3 Tahun 2018 tentang Penyelenggaraan dan Retribusi Parkir. Tujuan dibentuknya Peraturan Daerah Kota Batam Nomor 3 Tahun 2018 tentang Penyelenggaraan dan Retribusi Parkir adalah sebagai upaya peningkatan pelayanan dan memaksimalkan target penerimaan daerah dari penerimaan lainlain yang sah. Untuk pengamanan, sudah ada petugas yang bertanggung jawab. Masyarakat tidak perlu khawatir untuk memarkirkan kendaraannya.

Berdasarkan hasil wawancara di atas Dinas Perhubungan Kota Batam telah berperan sebagai regulator dalam menjalankan atau menegakkan Peraturan Daerah Kota Batam Nomor 3 Tahun 2018 tentang Penyelenggaraan dan Retribusi Parkir. Hal ini sesuai dengan peran pembentukan Dinas Perhubungan Kota Batam, dan apabila semua fungsi tersebut telah berjalan dengan baik, maka organisasi dapat dikatakan telah menjalankan perannya.

b. Fasilitator

Dinas Perhubungan Kota Batam sebagai fasilitator yang menciptakan kondisi yang kondusif bagi pengunjung kawasan wisata Barelang dan sekitarnya terus berupaya untuk melakukan yang terbaik dengan pengembangan pariwisata bekerjasama dengan Dinas Pariwisata. Pegawai Dinas Perhubungan Kota Batam, 
Hal ini dibenarkan oleh Dinas Kebudayaan dan Pariwisata Kota Batam, Ardiwinata mengatakan memang benar bahwa Pemerintah Pusat telah mengucurkan dana untuk pengembangan wisata Jembatan Barelang dan Dendang Melayu pada tahun 2019. Hal ini bertujuan agar pengunjung bisa lebih nyaman berkunjung ke Jembatan Barelang Kota Batam.

Berkaitan dengan beberapa penjelasan di atas dapat disimpulkan bahwa Dinas Perhubungan Kota Batam diberikan wewenang khusus sebagai penyidik untuk melakukan penyidikan tindak pidana di bidang pelanggaran peraturan daerah sebagaimana dimaksud dalam Undang-Undang Hukum Acara Pidana yang berlaku. Pemerintah Pusat dan Pemerintah Kota Batam bergerak di bidang pendampingan, pendanaan atau permodalan untuk pengembangan pariwisata khususnya kawasan wisata Jembatan Barelang dan sekitarnya.

c. Dinamisator

Peran Dinas Perhubungan Kota Batam sebagai dinamisator adalah menggerakkan partisipasi masyarakat beserta instansi pemerintah jika terjadi kendala-kendala dalam proses dalam menjalankan atau menegakkan Peraturan Daerah Kota Batam Nomor 3 Tahun 2018 tentang Penyelenggaraan dan Retribusi Parkir. Dalam hal ini Dinas Perhubungan Kota Batam berkoordinasi dengan Pihak Kepolisian dan Saber Pungli dalam melakukan penjaringan juru parkir liar yang melanggar Peraturan Daerah Kota Batam Nomor 3 Tahun 2018 tentang Penyelenggaraan dan Retribusi Parkir.

Staff UPTD Dinas Perhubungan Batam Andi Meiko, S.Tr mengatakan dalam melakukan penjaringan juru parkir liar Dinas Perhubungan Kota Batam berkoordinasi dengan Pihak Kepolisian dan Saber Pungli. Berkaitan dengan beberapa penjelasan di atas dapat disimpulkan bahwa Dinas Perhubungan Kota Batam telah berperan sebagai dinamisator menggerakkan partisipasi masyarakat beserta instansi pemerintah yaitu pihak kepolisian dan tim saber pungli Kota Batam. Semua pihak berkoordinasi dalam melakukan penjaringan juru parkir liar di kawasan wisata Jembatan Barelang dan sekitarnya. Selain itu pihaknya juga bekerjasama dengan masyarakat ataupun pengunjung.Jika ada informasi, langsung bergerak dan bertindak tegas untuk diamankan oleh Tim Saber Pungli Polresta Barelang. Pada bulan Januari 2019 sudah mengamankan dua orang jukir liar dengan barang bukti berupa tiket parkir bodong dan sejumlah uang sebesar Rp 445.000,- (empat ratus empat puluh lima ribu rupiah) dan sudah diproses sampai ke Pengadilan Negeri Batam. 


\section{Kesimpulan}

Berdasarkan hasil penelitian dan pembahasan yang telah diuraikan pada bab sebelumnya, adapun kesimpulan yang diperoleh adalah :

1. Pada peneltian ini diperlukan suatu pembangunan ekonomi yang harus dipandang sebagai suatu proses agar pola keterkaitan dan saling mempengaruhi antara faktor-faktor dalam pembangunan ekonomi dapat diamati dan dianalisis. Berdasarkan hasil observasi dan wawancara yang penulis lakukan di Jembatan Barelang, dapat diketahui bahwa biaya tarif untuk parkir yang diberikan tidak sesuai dengan Peraturan Daerah Kota Batam Nomor 3 Tahun 2018 tentang Penyelenggaraan dan Retribusi Parkir dan Sebelumnya Dinas Perhubungan Kota Batam menegaskan tidak ada aturan yang mengkhususkan tarif parkir untuk kawasan wisata. Jadi kalo ada pungutan itu merupakan pungutan liar, dan sampe saat ini pihak Dinas Perhubungan Kota Batam belum bisa ambil alih untuk mengelola parkir disana. Karena lokasi itu belum termasuk titik parkir. Titik parkir tersebut dari Walikota, dimana ada surat keputusannya dan tidak bukan. Masyarakat yang menjadi korban berhak tidak membayar dan melapor kepada aparat keamanan yang berada disana agar para juru parkir liar tersebut dapat ditindak tegas.

2. Dinas Perhubungan (Dishub) Kota Batam selaku dinas terkait yang ditunjuk Pemerintah Kota (Pemko) Batam untuk berperan penting dalam Menjalankan atau Menegakkan Peraturan Daerah Kota Batam Nomor 3 Tahun 2018 tentang Penyelenggaraan dan Retribusi Parkir Keterbatasan berperan sebagai berikut:

a. Regulator dimana Dinas Perhubungan Kota Batam memberikan acuan dasar kepada masyarakat. Acuan tersebut digunakan sebagai instrumen untuk mengatur segala kegiatan pelaksanaan Peraturan Daerah Kota Batam Nomor 3 Tahun 2018 tentang Penyelenggaraan dan Retribusi Parkir

b. Fasilitator dimana Dinas Perhubungan Kota Batam sebagai fasilitator yang menciptakan kondisi yang kondusif bagi pengunjung kawasan wisata Barelang dan sekitarnya terus berupaya untuk melakukan yang terbaik dengan pengembangan pariwisata bekerjasama dengan Dinas Pariwisata.

c. Dinamisator dimana peran Dinas Perhubungan Kota Batam sebagai dinamisator adalah menggerakkan partisipasi masyarakat beserta instansi pemerintah jika terjadi kendala-kendala dalam proses dalam menjalankan atau menegakkan Peraturan Daerah Kota Batam Nomor 3 Tahun 2018 tentang Penyelenggaraan dan Retribusi Parkir 


\section{Daftar Pustaka}

\section{Buku}

Anggara, Sahya, 2014, Kebijakan Publik, Bandung : CV Pustaka Setia Arsyad, Lincolin, 2010, Ekonomi Pembangunan, Yogyakarta: UPP STIM YKPN.

Bagir Manan, 1994, Dasar-Dasar Sistem Ketatanegaraan Republik Indonesia Menurut UUD 1945, Bandung : Universitas Padjajaran.

Ekaputra, H Nofidi, 2009, Kajian Pengembangan Strategi Di Wilayah Pesisir Kabupaten Pelalawan Provinsi Riau, Bogor : Institut Pertanian Bogor.

O. Notohamidjojo, 1970, Makna Negara Hukum, Jakarta : Badan Penerbit Kristen.

Soedjono D, 1983, Pungli Analisa Hukum Dan Kriminologi, Bandung : CV Sinar Baru.

Wahab A, 2016, Analisis Kebijakan, Jakarta : Bumi Aksara.

Winarno B, 2016, Kebijakan Publik Era Globalisasi, Yogyakarta : Caps Publishing.

\section{Undang-Undang}

Undang-undang Nomor 28 Tahun 2009 tentang Pajak Daerah dan Retribusi Daerah (Lembaran Negara Republik Indonesia Tahun. 2009 Nomor 130, Tambahan Lembaran Negara Republik Indonesia Nomor 5049)

Peraturan Daerah Kota Batam Nomor 3 Tahun 2018 tentang Penyelenggaraan dan Retribusi Parkir (Lembaran Daerah Kota Batam Tahun 2018 Nomor 3, Tambahan Lembaran Daerah Kota Batam Nomor 115).

\section{Jurnal}

La Sina, Dampak dan Upaya Pemberantasan serta Pengawasan Korupsi di Indonesia. Jurnal Hukum Pro Justisia. Vol 26 No 21, Januari 2008, hal 40

Irene Svinarky, Pemberantasan Tindak Pidana Korupsi Terhadap Pungutan Liar (PUNGLI), Jurnal Cahaya Keadilan. Vol 4. No 2 ISSN: 23391693

Samodra Wibawa, Arya Fauzy F.M, dan Ainun Habibah, Efektivitas Pengawasan Pungutan Liar di Jembatan Timbang. Jurnal Ilmu Administrasi Negara. Vol 12 No 2, Januari 201

\section{Internet}

https://www.batamnews.co.id/berita-43109-ada-pungli-di-jembatanbarelang-dispar-kami-fokus-tingkatkan-kunjungan.html, https://kbbi.web.id/liar https://www.academia.edu/28773677/Implementasi_Kebijakan_teori 